\title{
THE EFFECT OF IN VIVO AGING OF NORMAL HUMAN ERYTHROCYTES AND ERYTHROCYTE MACROMOLECULES UPON OXYHEMOGLOBIN DISSOCIATION *
}

\author{
By MILES J. EDWARDS, $\dagger$ ROBERT D. KOLER, DEMETRIOS A. RIGAS AND \\ DONALD M. PITCAIRN \\ (From the Department of Medicine and the Division of Experimental Medicine, University of \\ Oregon Medical School, Portland, Ore.)
}

(Submitted for publication September 30, 1960; accepted December 1, 1960)

Physical, chemical and metabolic alterations are known to occur during the in vivo aging of the normal human erythrocyte (1-16), including changes of hemoglobin molecular structure (1416). There have been no reports of the influence of erythrocyte age upon the erythrocyte's function of oxygen transport. Our purpose has been to determine whether a change in oxyhemoglobin dissociation occurs with aging of the normal human erythrocyte.

Any observed differences of oxyhemoglobin dissociation characteristics of old and young erythrocytes would require consideration of an age-dependent alteration of erythrocyte: metabolic activity, cell membrane function, electrolyte composition, small molecules and metabolites, and macromolecules, including hemoglobin itself. The plan of this study was designed to consider these possibilities by studies of hemoglobin: 1) contained within intact viable erythrocytes, and 2) freed of erythrocyte influence by hemolysis and subsequent dialysis.

\section{METHODS}

It has been well established that the aging erythrocyte increases in density $(5,7,10,11)$. Following conventional centrifugation of blood containing $\mathrm{Fe}^{59}$-labeled hemoglobin, several investigators have consistently observed that the top layers of the packed red cells contain cells of younger than average mean cell age, whereas the bottom layers contain cells of older than average mean cell age $(5,7,10,11)$. Ultracentrifugation modifies this technique only by applying a much greater gravitational force thereby improving the separation of cells according to age (11). Ultracentrifuga-

* Supported in part by Grant CY-3374 and a Fellowship Grant Award from the United States Public Health Service.

$\dagger$ This investigation was carried out during the tenure of a Postdoctoral Fellowship from the National Heart Institute, United States Public Health Service. tion is used in this study as the means of separating older cells from younger cells.

Oxyhemoglobin saturation was measured at an arbitrarily selected $\mathrm{P}_{\mathrm{O}_{2}}$ of $30 \mathrm{~mm} \mathrm{Hg}$ and $\mathrm{P}_{\mathrm{CO}_{2}}$ of $42 \mathrm{~mm}$ $\mathrm{Hg}$ in young and old intact erythrocytes, and in dialyzed hemolysates of young and old erythrocytes.

Intact erythrocytes. Blood samples were taken from the arm veins of 10 young, healthy, male medical students and interns. Heparin was used as an anticoagulant. Each sample was immediately cooled to $0^{\circ}$ to $4^{\circ} \mathrm{C}$ and maintained at this temperature, except where otherwise specified. The buffy coat was removed following brief preliminary centrifugation at $1,200 \mathrm{G}(2,600 \mathrm{rpm}$, radius $16 \mathrm{~cm}$ ). Ultracentrifugation for 2 hours at $67,-$ $000 \mathrm{G}$ at the tip $(22,500 \mathrm{rpm}$, radius $11.9 \mathrm{~cm})$ was carried out as described by Rigas and Koler (11). The Lusteroid containers were cut transversely and three equal layers of packed erythrocytes were separated, consisting of top, middle and bottom thirds; the middle third was discarded. The top and bottom thirds will be subsequently referred to as top layer cells and bottom layer cells, each nonspecifically as a cell layer. The cell layers were washed four times with separate samples of the subject's plasma, thereby removing all free hemoglobin. The packed top and bottom cell layers were separately suspended in samples of the subject's plasma, providing in each a hemoglobin concentration approximately equal to that of the original whole blood sample.

Equilibration of the cell layers with gas mixtures was accomplished in a modification of the open-circuit tonometer system of Björk and Hilty (17). The gas mixtures, prepared and stored under pressure in gas cylinders, were analyzed for their fractional compositions of oxygen and carbon dioxide by the Scholander microvolumetric gas analyzer (18). The temperature of the water bath was kept at $37.16^{\circ} \mathrm{C}\left( \pm 0.001^{\circ} \mathrm{C}\right)$. The gas mixture was finally ejected from the tonometer system at a measured depth under water. By varying this depth each day by an amount sufficient to compensate for fluctuations of barometric pressure, it was possible to maintain constancy of $\mathrm{P}_{\mathrm{O}_{2}}$ and $\mathrm{P}_{\mathrm{CO}_{2}}$ in the tonometer chamber. Under the conditions of this technique, equilibration of cell layer and gas mixture was always complete within 20 minutes.

The temperature of $37.16^{\circ} \mathrm{C}$ during equilibration permitted continuous glycolysis with accumulation of acid metabolites. The increasing acidity during the equili- 
bration period by itself decreased oxygen and carbon dioxide contents of the cell layers. (The use of glycolysis-inhibiting agents, such as sodium fluoride and diiodoacetate, always resulted in excessive hemolysis. By permitting glycolysis to occur, hemolysis was always avoided.) At a $\mathrm{P}_{\mathrm{O}_{2}}$ of $30 \mathrm{~mm} \mathrm{Hg}$ and $\mathrm{P}_{\mathrm{CO}_{2}}$ of $42 \mathrm{~mm} \mathrm{Hg}$, the simultaneous decrease of oxygen and carbon dioxide contents was curvilinear as shown in Figure 1. During equilibration at a $\mathrm{P}_{\mathrm{O}_{2}}$ of $147 \mathrm{~mm} \mathrm{Hg}$ and $\mathrm{P}_{\mathrm{CO}_{2}}$ of $42 \mathrm{~mm}$ $\mathrm{Hg}$ for the measurement of oxygen capacity, carbon dioxide content decreased without alteration of oxygen content.

In order to assess the relation of blood oxyhemoglobin to carbon dioxide content under changing conditions of acidity, each cell layer was separated into three 2 to $3 \mathrm{ml}$ aliquots, and each in turn was equilibrated in the tonometer chamber. Two of the aliquots were equilibrated at a $\mathrm{P}_{\mathrm{O}_{2}}$ of $30 \mathrm{~mm} \mathrm{Hg}$ and $\mathrm{P}_{\mathrm{CO}_{2}}$ of 42 $\mathrm{mm} \mathrm{Hg}$, one for 20 minutes and the other for $60 \mathrm{~min}$ utes. The third aliquot was equilibrated at a $\mathrm{P}_{0_{2}}$ of $147 \mathrm{~mm} \mathrm{Hg}$ and $\mathrm{P}_{\mathrm{CO}_{2}}$ of $42 \mathrm{~mm} \mathrm{Hg}$ for 20 minutes. Following equilibration, a small syringe moistened with heparin was attached to the aspirating needle. The tonometer gas was admitted to and expelled from the syringe six times. The equilibrated aliquots were then aspirated into the syringe and promptly analyzed for their oxygen and carbon dioxide contents by the Van Slyke-Neill manometric technique (19). Dissolved oxygen content was calculated (20) and subtracted from the total oxygen content to determine oxyhemoglobin content. The oxyhemoglobin content of the aliquot equilibrated at a $\mathrm{P}_{\mathrm{O}_{2}}$ of $147 \mathrm{~mm} \mathrm{Hg}$ was the oxygen capacity of its cell layer. The oxyhemoglobin percentage saturations of the aliquots equilibrated at a $\mathrm{P}_{\mathrm{O} 2}$ of $30 \mathrm{~mm} \mathrm{Hg}$ were then calculated. All studies were completed within 9 hours after collection of the blood sample.

Dialyzed clarified hemolysates. Blood samples from four young, healthy, male medical students and interns were processed by ultracentrifugation as described in the previous section. Each top and bottom cell layer was washed three or four times with isotonic saline. The cell layers were then hemolyzed by the addition of 2 or 3 vol of deionized water per vol of packed cells and were subsequently subjected to repeated rapid freezing and thawing. Each hemolysate prepared from the top layer cells or bottom layer cells will be subsequently referred to as a top layer hemolysate or bottom layer hemolysate, each nonspecifically as a cell layer hemolysate. The cell layer hemolysates were dialyzed against deionized water for 36 to 48 hours. Ultracentrifugation for 4 to 5 hours at $144,700 \mathrm{G}(40,000 \mathrm{rpm}$, radius 8.1 $\mathrm{cm})$ removed the stroma thereby clarifying the cell layer

TABLE I

Oxyhemoglobin and carbon dioxide contents of ultracentrifuged layers of erythrocytes after equilibration with gas mixtures containing a $\mathrm{P}_{\mathrm{CO}_{2}}$ of $42 \mathrm{~mm} \mathrm{Hg}$

\begin{tabular}{|c|c|c|c|c|c|c|c|c|}
\hline \multirow{3}{*}{$\begin{array}{c}\mathrm{Po}_{2}(\mathrm{~mm} \mathrm{Hg}) \\
\text { Equilibration } \\
\text { time (min) } \\
\text { Subject }\end{array}$} & \multicolumn{6}{|c|}{30} & \multicolumn{2}{|c|}{147} \\
\hline & \multicolumn{3}{|c|}{20} & \multicolumn{3}{|c|}{60} & \multicolumn{2}{|c|}{20} \\
\hline & $\mathrm{CO}_{2}$ & $\mathrm{HbO}_{2}$ & $\mathrm{HbO}_{2}$ & $\mathrm{CO}_{2}$ & $\mathrm{HbO}_{2}$ & $\mathrm{HbO}_{2}$ & $\mathrm{CO}_{2}$ & $\mathrm{HbO}_{2}$ \\
\hline & \multicolumn{2}{|c|}{ vol \% } & $\%$ sat. & \multicolumn{2}{|c|}{ vol \% } & $\%$ sat. & \multicolumn{2}{|c|}{ vol \% } \\
\hline \multicolumn{9}{|c|}{ Top layer } \\
\hline M.F. & 49.77 & 10.94 & 58.53 & 48.26 & 9.80 & 52.43 & 46.98 & 18.69 \\
\hline J.M. & 51.35 & 10.93 & 60.79 & 48.95 & 10.00 & 55.62 & 49.89 & 17.98 \\
\hline J.A. & 50.51 & 10.79 & 57.49 & 47.73 & 9.53 & 50.77 & 48.25 & 18.77 \\
\hline R.W. & 51.12 & 10.74 & 58.85 & 48.38 & 9.54 & 52.27 & 47.91 & 18.25 \\
\hline A.Ki. & 53.39 & 11.73 & 65.49 & 50.91 & 10.56 & 58.96 & 50.33 & 17.91 \\
\hline R.L. & 52.91 & 10.41 & 57.04 & 50.83 & 9.61 & 52.66 & 50.21 & 18.25 \\
\hline L.T. & 53.16 & 9.88 & 59.09 & 51.39 & 9.05 & 54.13 & 49.84 & 16.72 \\
\hline F.F & 53.43 & 10.60 & 61.24 & 52.13 & 9.75 & 56.33 & 52.03 & 17.31 \\
\hline C.C. & 53.38 & 11.64 & 59.91 & 49.80 & 10.40 & 53.53 & 49.61 & 19.43 \\
\hline A.Ke. & 51.29 & 12.09 & 60.85 & 49.20 & 11.36 & 57.17 & 50.75 & 19.87 \\
\hline Mean & 52.05 & 10.98 & 59.91 & 49.76 & 9.96 & 54.37 & 49.58 & 18.32 \\
\hline \multicolumn{9}{|c|}{ Bottom layer } \\
\hline M.F. & 49.95 & 10.99 & 60.52 & 47.64 & 10.17 & 56.00 & 47.94 & 18.16 \\
\hline J.M. & 52.92 & 11.99 & 67.21 & 51.14 & 11.39 & 63.85 & 50.36 & 17.84 \\
\hline J.A. & 50.28 & 11.32 & 64.25 & 49.02 & 10.27 & 58.29 & 48.63 & 17.62 \\
\hline R.W. & 51.71 & 12.21 & 61.64 & 49.49 & 11.47 & 57.90 & 49.81 & 19.81 \\
\hline A. Ki. & 51.74 & 12.36 & 68.33 & 50.27 & 11.52 & 63.68 & 49.91 & 18.09 \\
\hline R.L. & 53.73 & 11.12 & 63.98 & 52.27 & 10.51 & 60.47 & 52.97 & 17.38 \\
\hline L.T. & 52.42 & 10.71 & 64.48 & 51.00 & 10.04 & 60.45 & 50.89 & 16.61 \\
\hline F.F. & 55.66 & 11.77 & 67.53 & 53.47 & 10.76 & 61.73 & 53.86 & 17.43 \\
\hline C.C. & 53.02 & 11.82 & 64.48 & 50.65 & 10.79 & 58.87 & 50.38 & 18.33 \\
\hline A.Ke. & 51.81 & 12.57 & 68.06 & 51.10 & 12.10 & 65.51 & 48.81 & 18.47 \\
\hline Mean & 52.32 & 11.69 & 65.01 & 50.60 & 10.90 & 60.65 & 50.36 & 17.97 \\
\hline
\end{tabular}


hemolysate. Further ultracentrifugation at 144,700 G concentrated the hemoglobin to different extents in the different cell layer hemolysates.

Each cell layer hemolysate was divided into two 2 to 3 $\mathrm{ml}$ aliquots, and each of these was subjected to $20 \mathrm{~min}$ utes' equilibration. (Here, it was unnecessary to vary the duration of equilibration because no detectable glycolysis occurred.) One aliquot was equilibrated at a $\mathrm{P}_{\mathrm{O}_{2}}$ of $30 \mathrm{~mm} \mathrm{Hg}$ and $\mathrm{P}_{\mathrm{Co}_{2} \text { of }} 42 \mathrm{~mm} \mathrm{Hg}$, the other at a $\mathrm{P}_{\mathrm{O}_{2}}$ of $147 \mathrm{~mm} \mathrm{Hg}$ and $\mathrm{P}_{\mathrm{CO}_{2}}$ of $42 \mathrm{~mm} \mathrm{Hg}$. Oxygen and carbon dioxide contents were determined and further calculations were performed as in the previous section.

The $\mathrm{pH}$ of each aliquot equilibrated at a $\mathrm{P}_{\mathrm{O}_{2}}$ of 147 $\mathrm{mm} \mathrm{Hg}$ and $\mathrm{P}_{\mathrm{CO}_{2}}$ of $42 \mathrm{~mm} \mathrm{Hg}$ was determined in two studies using a Cambridge research model $\mathrm{pH}$ meter with temperature controlled at $37^{\circ}$ C. In one study, spectral analyses for methemoglobin were done using the Cary recording spectrophotometer. In another, inactive hemoglobin (primarily methemoglobin) contents were calculated by subtracting active hemoglobin contents (oxygen capacity/1.34) from total hemoglobin contents, determined by the cyanmethemoglobin method (21). All studies were completed within 4 days after collection of the blood sample.

\section{RESULTS}

Intact erythrocytes. Oxyhemoglobin and carbon dioxide contents of each cell layer are listed in Table I. For each period of equilibration, the carbon dioxide contents of top layer cells were generally lower than those of corresponding bottom layer cells, presumably due entirely to the greater rate of acid accumulation in the metabolically more active young cells $(4,5)$. Oxyhemoglobin saturations of top layer cells were always lower than those of corresponding bottom layer cells. Since there was unequal metabolic activity in the top and bottom cell layers, it became necessary to assess the role of glycolysis as a possible explanation for the different oxyhemoglobin saturations.

The raw data were analyzed by multiple regression using each oxyhemoglobin and carbon dioxide content of each cell layer as an independent variable for discrimination in comparing the oxyhemoglobin contents of corresponding top and bottom cell layers (22). This statistical treatment demonstrated that the different rates of glycolysis reflected in the different carbon dioxide contents could not account for all of this difference of oxyhemoglobin saturation. (Experimental validation of this is shown in the subsequent studies of dialyzed hemolysates.) The bottom layer cells had a significantly $(\mathrm{p}<0.05)$

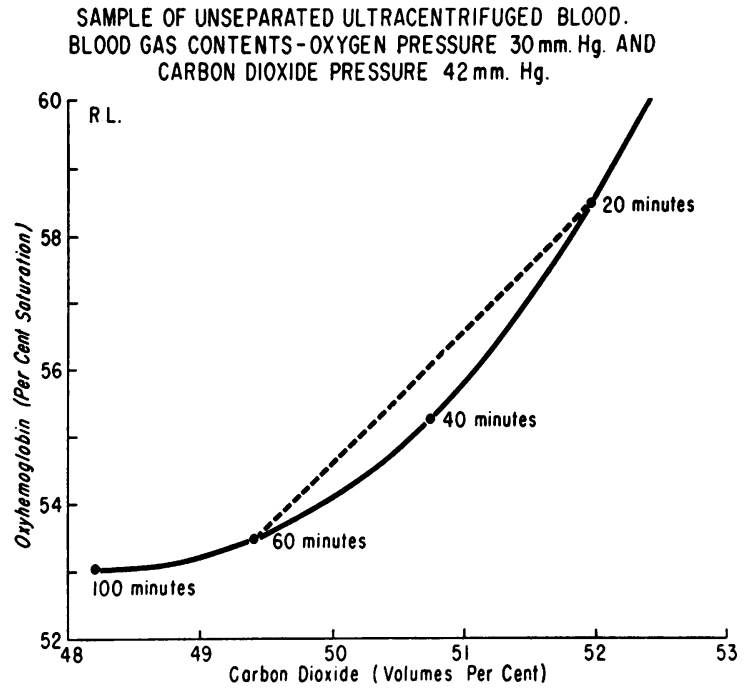

Fig. 1. The Relationship of equilibration time to BLOOD OXYHEMOGLOBIN SATURATIONS AND CARBON DIOXIDE CONTENTS.

greater oxyhemoglobin saturation than top layer cells under these conditions of equilibration.

Figure 1 demonstrates that the relation of oxyhemoglobin saturation to carbon dioxide content during continuing glycolysis is virtually linear between the twentieth and sixtieth minutes of equilibration. The mean values of the ten studies of intact cells are shown graphically in Figure 2. Straight lines have been assumed to represent the approximate pathway taken by the top and bottom cell layers in terms of oxyhemoglobin saturation and carbon dioxide content between the twentieth and sixtieth minutes of equilibration. Oxyhemoglobin saturations of top and bottom cell layers can be compared at any shared intercept of carbon dioxide content, thereby correcting for unequal metabolic activity. The oxyhemoglobin saturation difference between the mean top and bottom cell layer pathways is 4.35 per cent.

Dialyzed clarified hemolysates. The oxyhemoglobin and carbon dioxide contents, together with selected $\mathrm{pH}$ measurements, are listed in Table II. The bottom layer hemolysates had a 4.71 per cent greater mean oxyhemoglobin saturation than the top layer hemolysates. The variable oxygen capacities (reflecting variable hemoglobin concentrations) did not affect oxyhemoglobin saturation. The differences between the oxyhemoglobin saturations of corresponding top and bottom cell layer hemolysates were analyzed statis- 
Meon Blood Gos Contents - Oxygen Pressure 30mm.Hg. and Carbon Dioxide Pressure $42 \mathrm{~mm}$. $\mathrm{Hg}$.

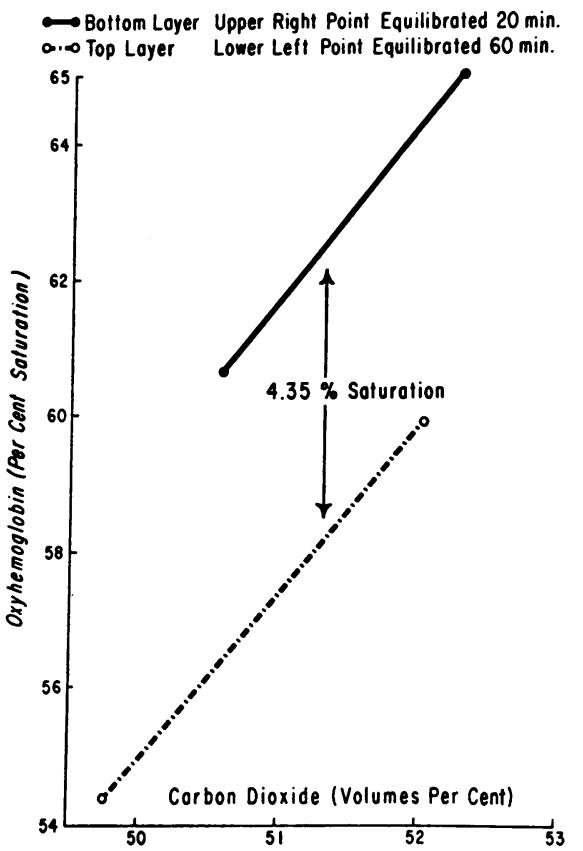

Fig. 2. The means of the OXYhemoglobin SATURATIONS AND CARBON DIOXIDE CONTENTS OF ALL TEN STUDIES OF TOP AND BOTTOM LAYERS OF ULTRACENTRIFUGED ERYTHROCYTES.

tically (22). The bottom layer hemolysates had a significantly $(p<0.05)$ greater oxyhemoglobin saturation than top layer hemolysates under these conditions of equilibration.

The $\mathrm{pH}$ values determined in two studies at a $\mathrm{P}_{\mathrm{O}_{2}}$ of $147 \mathrm{~mm} \mathrm{Hg}$ and $\mathrm{P}_{\mathrm{CO}_{2}}$ of $42 \mathrm{~mm} \mathrm{Hg}$ were essentially the same in corresponding top and bottom cell layer hemolysates. Methemoglobin was not detected in either top or bottom cell layer he-

TABLE II

Blood gas contents and $\mathrm{pH}$ of dialyzed hemolysates of ultracentrifuged layers of erythrocytes after 20 minutes' equilibration with gas mixtures containing a $P_{\mathrm{CO}_{2}}$ of $42 \mathrm{~mm} \mathrm{Hg}$

\begin{tabular}{|c|c|c|c|c|c|c|}
\hline \multirow{2}{*}{$\underset{\text { (mm }}{\mathrm{Po}_{2}} \mathrm{Hg}_{\text {Subject }}$} & \multicolumn{3}{|c|}{30} & \multicolumn{3}{|c|}{147} \\
\hline & $\mathrm{CO}_{2}$ & $\mathrm{HbO}_{2}$ & $\mathrm{HbO}_{2}$ & $\mathrm{CO}_{2}$ & $\mathrm{HbO}_{2}$ & $\mathrm{pH}$ \\
\hline & \multicolumn{2}{|c|}{$\begin{array}{l}\text { vol } \% \\
\text { op layer }\end{array}$} & $\%$ sat. & \multicolumn{2}{|c|}{ vol \% } & \\
\hline \multirow[t]{2}{*}{$\begin{array}{l}\text { M.F. } \\
\text { A.Ki. } \\
\text { C.C. } \\
\text { P.C. }\end{array}$} & $\begin{array}{r}10.50 \\
14.33 \\
10.49 \\
6.28\end{array}$ & $\begin{array}{l}4.40 \\
9.22 \\
5.02 \\
1.52\end{array}$ & $\begin{array}{l}52.01 \\
62.94 \\
50.60 \\
48.25\end{array}$ & $\begin{array}{r}10.17 \\
13.81 \\
10.18 \\
6.48\end{array}$ & $\begin{array}{r}8.46 \\
14.65 \\
9.92 \\
3.15\end{array}$ & $\begin{array}{l}6.70 \\
6.59\end{array}$ \\
\hline & \multicolumn{3}{|c|}{ Bottom layer } & & & \\
\hline $\begin{array}{l}\text { M.F. } \\
\text { A.Ki. } \\
\text { C.C. } \\
\text { P.C. }\end{array}$ & $\begin{array}{r}10.73 \\
14.35 \\
9.85 \\
8.02\end{array}$ & $\begin{array}{r}5.13 \\
10.94 \\
5.13 \\
3.03\end{array}$ & $\begin{array}{l}53.22 \\
67.41 \\
56.19 \\
55.80\end{array}$ & $\begin{array}{r}11.02 \\
13.72 \\
9.07 \\
8.02\end{array}$ & $\begin{array}{r}9.64 \\
16.23 \\
9.13 \\
5.43\end{array}$ & $\begin{array}{l}6.71 \\
6.58\end{array}$ \\
\hline
\end{tabular}

TABLE III

Comparison of total and active hemoglobin of dialyzed hemolysates of ultracentrifuged layers of erythrocytes of Subject C.C.

\begin{tabular}{lcccc}
\hline \hline Layer & $\begin{array}{c}\text { Total } \\
\text { hemo- } \\
\text { globin }\end{array}$ & $\begin{array}{c}\text { Active } \\
\text { hemo- } \\
\text { globin }\end{array}$ & $\begin{array}{c}\text { Inactive } \\
\text { hemo- } \\
\text { globin }\end{array}$ & $\begin{array}{c}\frac{\text { Oxygen }}{\text { capacity }} \\
\text { total } \\
\text { hemo- } \\
\text { globin }\end{array}$ \\
\hline Top & $g \%$ & $g \%$ & $g \%$ & $\mathrm{gl} / \mathrm{g}$ \\
Middle & 7.6 & 7.40 & $\mathbf{+ 0 . 2 0}$ & $\mathbf{1 . 3 1}$ \\
Bottom & 7.1 & 7.22 & -0.12 & 1.36 \\
\hline
\end{tabular}

molysates, in the two studies performed, either by spectrophotometry or by determination of inactive hemoglobin (see Table III). There was no apparent alteration with age of the normal oxygen capacity-hemoglobin ratio (normally 1.34 $\mathrm{ml} \mathrm{O}_{2}$ per gram $\mathrm{Hb}$ ).

\section{DISCUSSION}

Erythrocyte aging has been studied by the techniques of serial osmotic hemolysis $(12,13)$; differential agglutination, sparing transfused donor cells (23-25); and centrifugation $(5,7,10$, 11). It has been established that numerous changes occur during the life span of the mature circulating erythrocyte. Enzymatic activity (1-6) and anaerobic glycolysis $(4,5)$ decrease. Potassium concentration decreases with a rise in sodium concentration $(5,7)$. A controversy exists $(8,9)$ as to whether methemoglobin concentration may increase. The minor hemoglobin components, $A_{3}$ and $A_{1}$, increase with a reduction of major hemoglobin $A(14,15)$. Osmotic fragility increases $(12,13)$. Erythrocyte lipid content decreases, causing diminished cell size and increased cell density $(5,7)$.

At a $\mathrm{P}_{\mathrm{O}_{2}}$ of $30 \mathrm{~mm} \mathrm{Hg}$ and $\mathrm{P}_{\mathrm{CO}_{2}}$ of $42 \mathrm{~mm} \mathrm{Hg}$, the older intact erythrocytes have an average of 4.35 per cent greater oxyhemoglobin saturation than the younger erythrocytes. The difference between the old and young cells at one point on the oxyhemoglobin dissociation curve confirms their dissimilarity.

Many factors act upon hemoglobin to influence its property of reversible combination with oxygen : $\mathrm{pH}(26), \mathrm{CO}_{2}$ (27), temperature (28), electrolyte environment (29-32), cell thickness (33), carbonic anhydrase (34), ascorbic acid (34), sulfhydryl groups of cysteine and glutathione (35), 
sulfhydryl groups of hemoglobin (36-38), the spatial arrangement of the four heme groups within the hemoglobin molecule $(39,40)$, and the presence of the inactive forms of hemoglobin, carbonmonoxyhemoglobin (41) and methemoglobin (42).

It was not clear, however, from the studies of viable, intact cells whether these or other factors were responsible for the observed change in oxyhemoglobin dissociation with age. Hemolysis followed by dialysis and removal of the stroma destroyed not only the erythrocyte membrane but also its metabolism by effectively removing all ions and metabolic participants. The residue contained only the soluble erythrocyte macromolecules, principally hemoglobin. The $\mathrm{pH}$ of the oxygen-saturated hemolysates was essentially that of isoelectric oxyhemoglobin. Oxyhemoglobin saturation was significantly greater in the dialyzed hemolysates of old cells than in those of young cells and was comparable in magnitude to that observed between old and young intact cells. It was concluded, therefore, that the age-dependent dissimilarity in oxyhemoglobin saturations of intact cells and their dialyzed hemolysates was attributable to alterations of erythrocyte macromolecules.

Such a technique does not exclude the possible influence of methemoglobin. According to Darling and Roughton, a 14 per cent (of total hemoglobin) concentration of methemoglobin is necessary to effect a 4 to 5 per cent increase of oxyhemoglobin saturation in hemolysates in this part of the oxyhemoglobin dissociation curve (42). Waller, Schlegel, Müller and Löhr found a methemoglobin concentration of 8 per cent of total hemoglobin in erythrocytes surviving 80 days after transfusion (8). Betke, Baltz, Kleihauer and Scholz, however, measured mean methemoglobin concentrations of only 0.6 per cent of total hemoglobin in the top and bottom layers of centrifuged erythrocytes (9). Our failure to detect methemoglobin makes it unlikely that the observed differences of oxyhemoglobin saturation could be explained on this basis.

The results of Meyering, Israels, Sebens and Huisman (15) demonstrate a partial conversion with age of normal hemoglobin $A_{0}$ to the minor hemoglobin $A_{1}$. They observed no difference, however, in the oxygen affinity of these two he- moglobins which were prepared from erythrocytes not separated according to age. The high oxyhemoglobin affinity of hemoglobin $A_{2}$ (15) does not explain our results, since this hemoglobin did not increase as erythrocytes aged.

The macromolecules of dialyzed, stroma-free hemolysates consist principally of hemoglobin, about 99.2 per cent by weight (43). Other nondialyzable components include enzymes whose alterations with age have been described. The substrates upon which the enzymes normally act, however, have been removed by dialysis. Other macromolecules are unknown and, if present, probably exist only in minute amounts. In a preliminary study of major hemoglobin A isolated by starch grain electrophoresis, its oxyhemoglobin saturation at a $\mathrm{P}_{\mathrm{O}_{2}}$ of $30 \mathrm{~mm} \mathrm{Hg}$ and $\mathrm{P}_{\mathrm{CO}_{2}}$ of 42 $\mathrm{mm} \mathrm{Hg}$ was greater in a sample prepared from the bottom layer hemolysate than in that prepared from the top layer hemolysate. These facts together indicate that a macromolecular alteration has probably occurred in the hemoglobin molecule itself.

This study has demonstrated an alteration of oxygen dissociation properties of normal hemoglobin as a result of in vivo erythrocyte aging. Such a change in the function of a normal protein presumably reflects an age-dependent alteration of its structure. In this instance, however, altered structure is not the result of proteolysis since aged hemoglobin retains a normal oxygen capacity. This may be secondary to an in vivo erythrocyte metabolic alteration or an independent and spontaneous molecular change. This study, together with the previously reported molecular alterations of hemoglobin (14-16) and of lens proteins (44) with age, supports the concept that proteins in their physiological environment may undergo with age a molecular alteration other than proteolysis, impairing the function and/or viability of the cells $(16,45)$.

Further studies are now in progress to define more fully the effect of cell age upon the oxyhemoglobin dissociation curve and to determine the nature of the postulated hemoglohin molecular change.

\section{SUMMARY}

1. Oxyhemoglobin dissociation properties of old and young normal human erythrocytes and their 
dialyzed hemolysates have been compared. The different densities of old and young erythrocytes permitted their separation by ultracentrifugation.

2. Old and young intact erythrocytes obtained from ten normal subjects were separately equilibrated at $37.16^{\circ} \mathrm{C}$ with a $\mathrm{P}_{\mathrm{O}_{2}}$ of $30 \mathrm{~mm} \mathrm{Hg}$ and $\mathrm{P}_{\mathrm{CO}_{2}}$ of $42 \mathrm{~mm} \mathrm{Hg}$. Old erythrocytes had a significantly greater oxyhemoglobin saturation than young erythrocytes $(\mathrm{p}<0.05)$.

3. Dialyzed and clarified hemolysates of old and young erythrocytes from four normal subjects were separately equilibrated at $37.16^{\circ} \mathrm{C}$ with a $\mathrm{P}_{\mathrm{O}_{2}}$ of $30 \mathrm{~mm} \mathrm{Hg}$ and $\mathrm{P}_{\mathrm{CO}_{2}}$ of $42 \mathrm{~mm} \mathrm{Hg}$. (Hemolysates dialyzed against deionized water contain only erythrocyte macromolecules.) The dialyzed hemolysates of old erythrocytes had a significantly greater oxyhemoglobin saturation than the dialyzed hemolysates of young erythrocytes $(\mathrm{p}<0.05)$. It was concluded that the difference in oxyhemoglobin dissociation of young and old intact erythrocytes is attributable to alteration of erythrocyte macromolecules.

4. The age-dependent alteration in the function of normal hemoglobin is probably due to an alteration within its molecule. This supports the hypothesis that normal proteins may change in structure as a result of aging.

\section{ACKNOWLEDGMENTS}

The authors are indebted to Miss Katherine Swisher and Mr. George Cummings for technical assistance and to Dr. Carl Hopkins for assistance in the statistical analysis.

\section{REFERENCES}

1. Allison, A. C., and Burn, G. P. Enzyme activity as a function of age in the human erythrocyte. Brit. J. Haemat. 1955, 1, 291.

2. Schlegel, B., and Kappest, P. Untersuchungen zur intravitalen Erythrocytolyse. Klin. Wschr. 1956, 34, 805.

3. Marks, P. A., Johnson, A. B., and Hirschberg, E., Effect of age on the enzyme activity in erythrocytes. Proc. nat. Acad. Sci. (Wash.) 1958, 44, 529.

4. Löhr, G. W., Waller, H. D., Karges, O., Schlegel, B., and Müller, A. A. Zur Biochemie der Alterung menschlicher Erythrocyten. Klin. Wschr. 1958, 36, 1008.

5. Bernstein, R. E. Alterations in metabolic energetics and cation transport during aging of red cells. J. clin. Invest. 1959, 38, 1572.

6. Rigas, D. A., and Koler, R. D. Erythrocyte enzymes and reduced glutathione in hemoglobin $\mathrm{H}$ disease; relation to cell age and denaturation of hemoglobin H. J. Lab. clin. Med. In press.

7. Prankerd, T. A. J. The ageing of red cells. J. Physiol. (Lond.) 1958, 143, 325.

8. Waller, H. D., Schlegel, B., Müller, A. A., and Löhr, G. W. Der Hämiglobingehalt in alternden Erythrocyten. Klin. Wschr. 1959, 37, 898.

9. Betke, K., Baltz, A., Kleihauer, E., and Scholz, P. Methämoglobingehalt, Methämoglobinreduktion und Sauerstoffverbrauch in jungen und alten Erythrozyten. Blut 1960, 6, 203.

10. Borun, E. R., Figueroa, W. G., and Perry, S. M. The distribution of $\mathrm{Fe}^{59}$ tagged human erythrocytes in centrifuged specimens as a function of cell age. J. clin. Invest. 1957, 36, 676.

11. Rigas, D. A., and Koler, R. D. Ultracentrifugal fractionation of human erythrocytes on the basis of cell age. J. Lab. clin. Med. In press.

12. Marks, P. A., and Johnson, A. B. Relationship between the age of human erythrocytes and their osmotic resistance: A basis for separating young and old erythrocytes. J. clin. Invest. 1958, 37, 1542.

13. Simon, E. R., and Topper, Y. J. Fractionation of human erythrocytes on the basis of their age. Nature (Lond.) 1957, 180, 1211.

14. Kunkel, H. G., and Bearn, A. G. Minor hemoglobin components of normal human blood. Fed. Proc. 1957, 16, 760 .

15. Meyering, C. A., Israels, A. L. M., Sebens, T., and Huisman, T. H. J. Studies on the heterogeneity of hemoglobin. II. The heterogeneity of different human hemoglobin types in carboxymethylcellulose and in amberlite IRC-50 chromatography; quantitative aspects. Clin. chim. Acta 1960, 5, 208.

16. Rigas, D. A., and Koler, R. D. Decreased erythrocyte survival in hemoglobin $\mathrm{H}$ disease as a result of the abnormal properties of hemoglobin $\mathrm{H}$; the benefit of splenectomy. Blood. In press.

17. Björk, V. O., and Hilty, H. J. Microvolumetric determination of $\mathrm{CO}_{2}$ and $\mathrm{O}_{2}$ tensions in arterial blood. J. appl. Physiol. 1954, 6, 800.

18. Scholander, P. F. Analyzer for accurate estimation of respiratory gases in one-half cubic centimeter samples. J. biol. Chem. 1947, 167, 235.

19. Van Slyke, D. D., and Neill, J. M. The determination of gases in blood and other solutions by vacuum extraction and manometric measurement. J. biol. Chem. 1924, 61, 523.

20. Sendroy, J., Jr., Dillon, R. T., and Van Slyke, D. D. Studies of gas and electrolyte equilibria in blood. XIX. The solubility and physical state of uncombined oxygen in blood. J. biol. Chem. 1934, $105,597$.

21. Crosby, W. H., Munn, J. I., and Furth, F. W. Standardizing a method for clinical hemoglobinometry. U. S. armed Forces med. J. 1954, 5, 693.

22. Johnson, P. O. Statistical Methods in Research. New York, Prentice-Hall, 1949, pp. 75, 347. 
23. Ashby, W. The determination of the length of life of transfused blood corpuscles in man. J. exp. Med. 1919, 29, 267.

24. Dacie, J. V., and Mollison, P. L. Survival of normal erythrocytes after transfusion to patients with familial haemolytic anaemia (acholuric jaundice). Lancet 1943, 1, 550.

25. Schlegel, B. Agglutination der durch Isoantikörper inagglutinablen Erythrocyten mit hilfe von Phytagglutininen. Klin. Wschr. 1957, 35, 680.

26. Barcroft, J., Bock, A. V., Hill, A. V., Parsons, T. R., Parsons, W., and Shoji, R. On the hydrogen-ion concentration and some related properties of normal human blood. J. Physiol. (Lond.) 1922, 56, 157.

27. Bohr, C., Hasselbalch, K., and Krogh, A. Ueber einen in biologischer Beziehung wichtigen Einfluss, den die Kohlensäurespannung des Blutes auf dessen Saurerstoffbindung übt. Skand. Arch. Physiol. 1904, 16, 402.

28. Brown, W. E. L., and Hill, A. V. The oxygen-dissociation curve of blood, and its thermodynamical basis. Proc. roy. Soc. B 1923, 94, 297.

29. Barcroft, J., and Camis, M. The dissociation curve of blood. J. Physiol. (Lond.) 1909, 39, 118.

30. Kono, H. On the influence of salts upon the dissociation curve of haemoglobin. Jap. J. med. Sci., III. Biophysics 1931, $2,1$.

31. Sidwell, A. E., Jr., Munch, R. H., Barron, E. S. G., and Hogness, T. R. The salt effect on the hemoglobin-oxygen equilibrium. J. biol. Chem. 1938, $123,335$.

32. Burke, J. D. The effects of different salt concentrations on the affinity of hemoglobin for oxygen. J. cell. comp. Physiol. 1959, 54, 126.

33. Valtis, D. J., and Baikie, A. G. The influence of red-cell thickness on the oxygen dissociation curve of blood. Brit. J. Haemat. 1955, 1, 146.

34. Horejsi, J., and Komarkova, A. The influence of some factors of the red blood cells on the oxygen- binding capacity of haemoglobin. Clin. chim. Acta 1960, 5, 392.

35. Horejsi, J., and Komarkova, A. The effect of SHgroups on the affinity of haemoglobin to oxygen. Clin. chim. Acta 1958, 3, 131.

36. Riggs, A. F. Sulfhydryl groups and the interaction between the hemes in hemoglobin. J. gen. Physiol. $1952,36,1$.

37. Riggs, A. F., and Wolbach, R. A. Sulfhydryl groups and the structure of hemoglobin. J. gen. Physiol. 1956, 39, 585.

38. Murayama, M. Discussion: Conformational differences of mercapto groups of four hemoglobins. Fed. Proc. 1957, 16, 756.

39. Pauling, L. The oxygen equilibrium of hemoglobin and its structural interpretation. Proc. nat. Acad. Sci. (Wash.) 1935, 21, 186.

40. Wyman, J., Jr. Heme proteins. Advanc. Protein Chem. 1948, 4, 407.

41. Roughton, F. J. W., and Darling, R. C. The effect of carbon monoxide on the oxyhemoglobin dissociation curve. Amer. J. Physiol. 1944, 141, 17.

42. Darling, R. C., and Roughton, F. J. W. The effect of methemoglobin on the equilibrium between oxygen and hemoglobin. Amer. J. Physiol. 1942, 137, 56.

43. Behrendt, H. Chemistry of Erythrocytes: Clinical Aspects. Springfield, Ill., Charles C Thomas, 1957, p. 56.

44. Dische, Z. Glutathione and protein oxidation and precipitation in the process of aging and cataract formation in the lens in Glutathione. A Symposium, S. Colowick, A. Lazarow, E. Racker, D. R. Schwarz, E. Stadtman and H. Waelsch, Eds. New York, Academic Press, 1954, p. 296.

45. Rigas, D. A., Koler, R. D., and Osgood, E. E. Hemoglobin $H$. Clinical, laboratory, and genetic studies of a family with a previously undescribed hemoglobin. J. Lab. clin. Med. 1956, 47, 51.

\section{SPECIAL NOTICE TO SUBSCRIBERS}

Post Offices will no longer forward the Journal when you move.

Please notify The Journal of Clinical Investigation, Business

Office, 333 Cedar Street, New Haven 11, Conn., at once when you have a change of address, and do not omit the zone number if there is one. 